\title{
選択的吸い込みによる横流れ不安定場の制御*
}

\author{
江 上 泰 広*1, 小濱 泰 昭*2
}

\section{Control of Crossflow Instability Field by Selective Suction System}

\author{
EGAMI Yasuhiro and KOHAMA Yasuaki
}

\begin{abstract}
A full turbulent transition process is created on a yawed flat plate using a displacement body system in a wind tunnel. It was found that high frequency secondary instability drives the crossflow dominant boundary layer into a full turbulent state. Taking into account such transition structures, effective control of the flow field to delay the transition is possible. That is, by placing grooving line suction holes along each streamwise crossflow vortex, and as is causing selective suction in the low momentum flow, the appearance of the secondary instability is successfully delayed turbulent transition. This suction system also has an advantage over a uniform system in that the amount of suction air volume required to control the flow field is much less than in uniform suction. Thus, a great deal of energy needed for flow control is saved. We also attempted to determine the most appropriate condition for selective suctioning.
\end{abstract}

Key Words: Turbulent Transition, Three-Dimensional Boundary Layer, Aircraft Drag Reduction, Crossflow Instability, Secondary Instability, Selective Suction Technique

\section{1. 緒言}

次些代旅客機を開発する上で，ペイロードの问上を 网ることは重要なデザインコンセプトの一つとなって いる．見住の航空機では，要音速領域での造波抵抗を城 少させるために主翼に後退翼が採用されている。しか し後还翼表面上の境界層は，玨力勾配の力向と主流の 方的が瞋なるためにねじれた形となり三次元境界绝を 形成する. その絬果三次元化した境界層の乱流遷移は， 二次元的な境界層のそれと比べて早まることが知られ て扝り，この現象は横流れ不安定性と呼ばれ(1)(2)様々な 研究がなされてきている。

航空機の更なる抵抗軽珹のためには，このような後 退翼」:の流れを绝流制御する必要がある。しかしこの 三次元境界角を層流化する技術は非常に難しく，末だ 有效なものは考案されていない，有効な制御を実現す るためには，翼表面で起こる横流れ不安定性による三 次元境界曆の乱流遷移のメカニズムを十分に理解しな ければならず，そのため多くの研究者がこの問題に実

\footnotetext{
* 原稿曼付 1996 年 11 月2211.

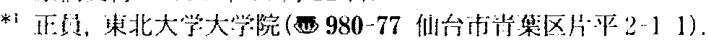

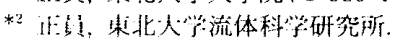

験(3) (5)，数值解析 ${ }^{(6)} \sim(8) ， の$ 雨面から精力的に收り組儿 できている.

これまで我々は, Saric \& Yeats ${ }^{\left({ }^{(9)}\right.}$ にって考条され た上部に王力印加物体を設琶した後退壮板モデルを 導入し，横流れ不安定性に間子る奏験を行ってきてい

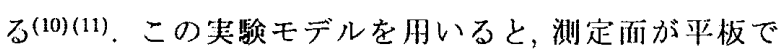
あるため壁面の曲率は考虑しなくて済み，後拈翟モデ ルでは腾加た境界層厚さも制御できる。また同じ流 れ条件を保ったまま流速を変化させることができるな ど, 测定する上で後退翼モデルと比べて様々な利点を有 している．何よりも流れ場を倐御しようとするときに 㥛めて便利である，我々はこの奏検モデル上に居流か ら乱流に至る全ての迕移過程を再現し，透移過程の妓 終段階を熱線流速計と可視化法を件用して絴紐に湖心゙ てきた。 その結果, 横流れ不安定性が支配的尔境界局 における乱流遷移は，その遷移最終段階で生じる高楇 波二次不安定性によって引き起こされていることが分 かった(10)(11). そして，得られた流れの遥移機模の情被 を基に僄移構造を考慮した選択吸い込みを行い，橔流 れ不安定場の有效制御を試みている。 その結果一様吸 い込みの場合と比較し，より少ないエネルギーで刘果 的に高周波二次不安定性の発生を遅らせることに成以 した. 


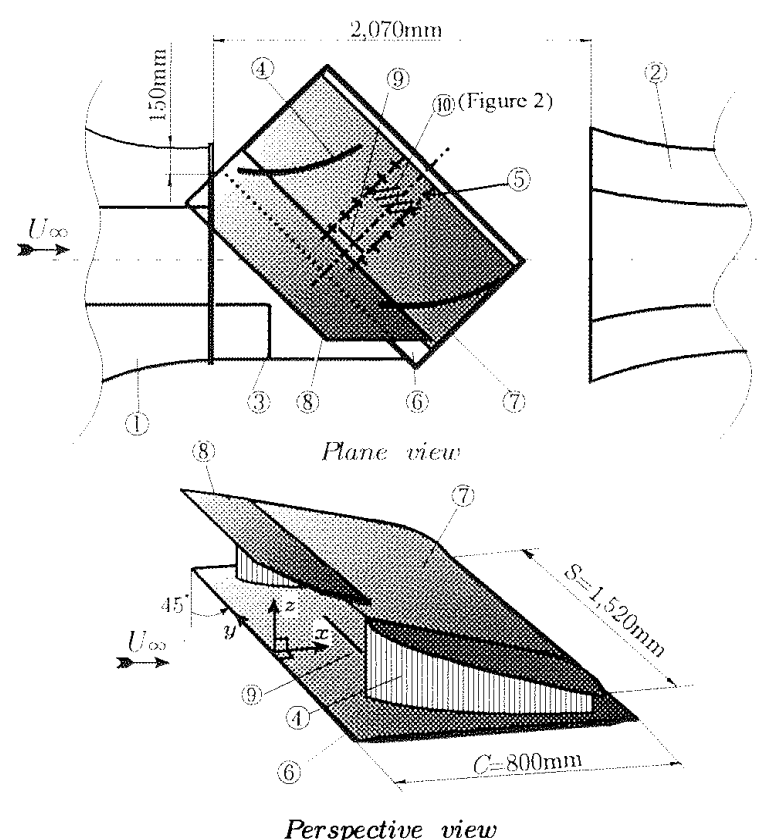

(1) wind tunnel contraction nozzle (2) wind tunnel collector

(3) extended nozzle (4) side plate (5) pressure taps (6) flat plate

(7) displacement body (8) separation preventing plate

(9) smoke visualization slit (10) suction slits

Figure 1. Experimental set-ups and coordinate system

本研究では，さらに様々な条件下における選択吸い込 みによる制御を行い，最適な吸い込み条件を明らかに することを目的とした実験を行っている。

\section{2. 実験装置および測定方法}

図1に実験装置の概略を示寸。後退角 $45^{\circ}$ の圧力印加 物体と平板との組み合わせにより，単調减少する圧力 分布を作りだしている. 圧力勾配の方向は主流と $45^{\circ}$ の角度を成しており，その結果三次元境界層が形成さ れる.このような装置により後退翼上の境界層と類似 の横流れ不安定性が支配的な境界層を形成し，条件を 調整することにより完全乱流までの全遷移過程を作り 出すことができた。圧力印加物体にはNACA0015翼形 を用い，その弦長は600 mm，スパン長は $1520 \mathrm{~mm}$ である. 圧力印可物体の迎角および平板に対する位置は任意に 変化させることができ, 従って任意の圧力分布を平板上 に印加することができる. 平板の弦長は $C=800 \mathrm{~mm}$ であ り,前縁には20:1の修正棈円形状(12)を採用し, 前縁部と 平板との間で曲率の接続が滑らかになるように設計さ れている.このようにすることで，横流れ不安定性以 外の擋乱の侵入を防ぐことができる. 平板表面には48 個の静压孔が弦长方向に設けられており，平板表面の 圧力分布を正確に测定することができる. また風洞壁 に発達寸る境界層による前縁污染(13)を防ぐために，後 退平板の上流側の端は，図1に示すように風洞壁から $150 \mathrm{~mm}$ 離して設置した。 さらに無限翼を模擬するため
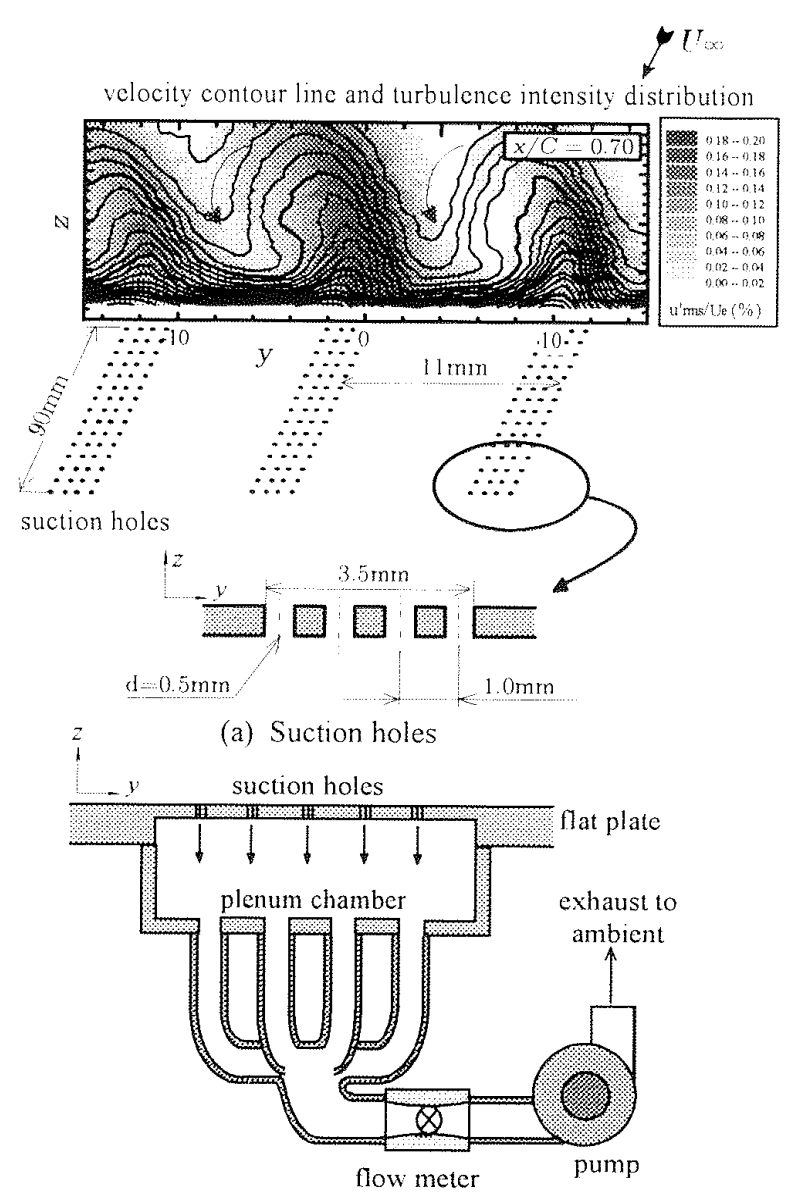

(b) Flow path

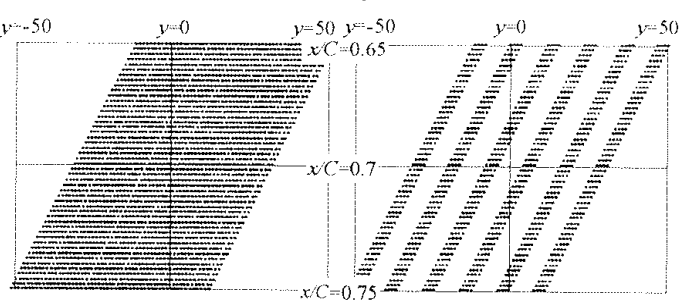

[A] uniform suction holes [B] line suction holes

(c) Arrangements of suction surfaces

Figure 2. Details of the suction system

に,ポテンシャル流線の曲率を有する侧板を平板と压力 印加物体の閒に設置した。 また用いた吸い込み装置の 詳細図を図 2 に示す。吸い込みには, (c) 図の[A]一様吸 い込み, $[\mathrm{B}]$ 選択吸い込みの 2 種類を用いた. $[\mathrm{A}],[\mathrm{B}] 0$ 吸 い込み孔はともに直径 $0.5 \mathrm{~mm}$, 孔間隔は $1 \mathrm{~mm}$ ピッチであ

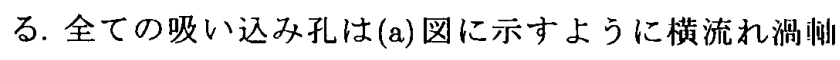
に沿って設けてある(主流に対して $17.7^{\circ}$ ). [B]の選択吸 い込みでは，吸い込み孔 4 列(スパン方向に $3.5 \mathrm{~mm})$ を渦 間隔に合わせスパン方向に $11 \mathrm{~mm}$ 周期に設けてある.

吸い込みは層流領域である $x / C=0.20 \sim 0.30$ の位䡒と 遷移領域である $x / C=0.65 \sim 0.75$ の位置の 2 箇所で試みた。 取り込まれた空気は図(b)のように平板裏側に取り付 けられたプレナムチャンバーからパイプを経て遠心フ アンにより吸い込まれ，流量計によりその量が計测さ 


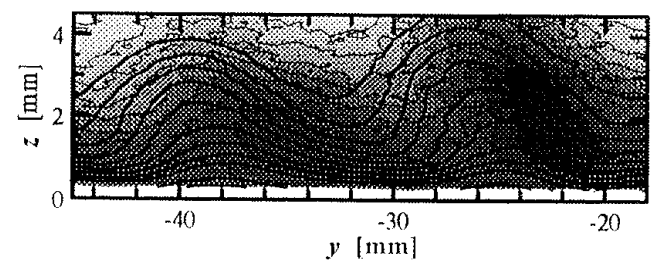

(a) no suction

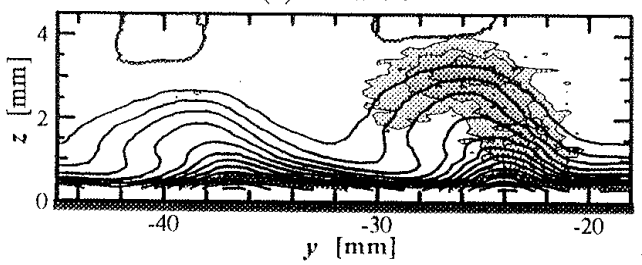

(b) uniform suction holes

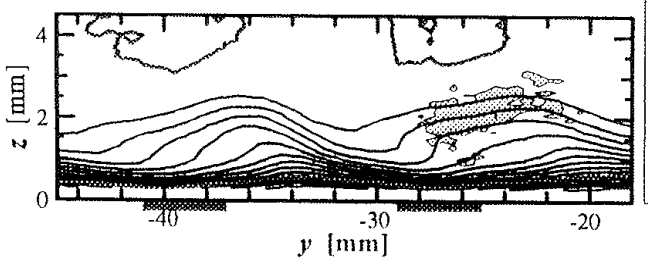

(c) line suction holes

Figure 3. Cross sectional measurement of velocity and turbulence intensity profiles for different suction surfaces (velocity contour line step: $5 \%$ of $U e$, Bandpass filter range : $1.25-3 \mathrm{kHz}$ for disturbance $f 2$, $x / C=0.79, U_{\infty}=12.3 \mathrm{~m} / \mathrm{s}$, Suction volume $0.045 \mathrm{~m}^{3} / \mathrm{m}^{2} \cdot \mathrm{s}$, minmm indicates suction positions)

れる。

测定には東北大学流体科学研究所の低乱熱伝達風 洞(14)を用い，测定部を開放型にして使用した。测定部 上流端のノズル吹き出し口は対辺距離が $1010 \mathrm{~mm}$ の正 八角形で, 测定部の長さは $2070 \mathrm{~mm}$ である.

流速の测定には熱線流速計を用い, I型の熱線プロー ブより得られた信号は, A/D変換されてコンピェーター に取り込まれ処理される.そして必要に応じてFFTア ナライザーにより解析される. 熱線流速計による流速 测定は0.7\%以内の不確かさで校正されている.また熱 線プローブは,コンピューター制御された $1 / 100 \mathrm{~mm}$ の精 度を有する三次元トラバース装置によってトラバース される. 奏験は主流速度 $U_{\infty}=12.3 \mathrm{~m} / \mathrm{s}$ (平板の弦長 $C$ 基準のレイノルズ数 $\left.R e=U_{\infty} C / \nu=6.9 \times 10^{5}\right)$ で行 っている.このときの主流の乱れ強さは，モデルを取

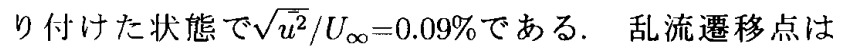
$U_{\infty}=12.3 \mathrm{~m} / \mathrm{s} \sigma$ 場合で $x / C=0.77$ 付近である.

\section{3. 結果および考察}

$3 \cdot 1$ 邉移領域の吸い込みこれまで乱流遷移を 遅らせ, 粘性抵抗を娍少させるために様々な層流制御が 試みられてきた，層流境界層の一様吸い込みによる制 御もその中の一つである.しかし流れ場を一様に吸い 込むためには膨大なエネルギーが必要であり，また三 次元境界層の場合, 必ずしも良好な結果が得られると

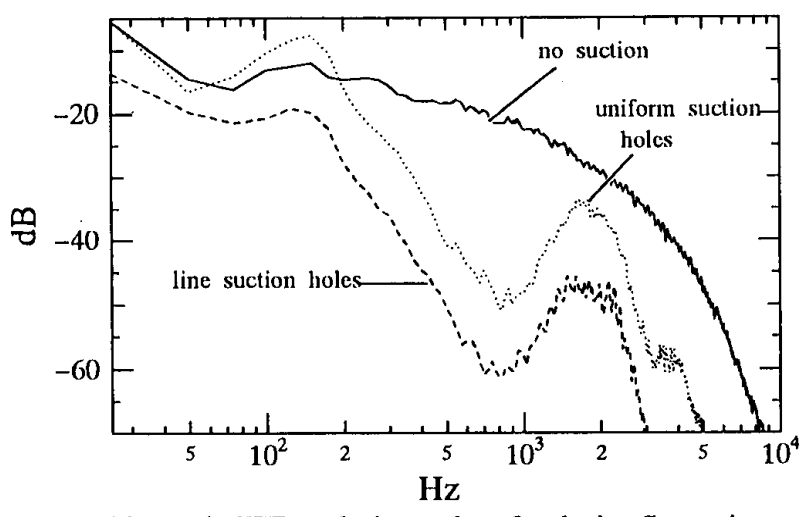

Figure 4. FFT analysis results of velocity fluctuations at a crossflow vortex $\left(U_{\infty}=12.3 \mathrm{~m} / \mathrm{s}, x / C=0.79, z=1.2 \mathrm{~mm}\right)$

いう報告はなされていない。そこで我々は，流れ場の 遷移機構を考虑に入れた選択吸い込みを行うことによ り，少ない吸い込み量で効果的な制卸を行うことを初 みた。当初, 縦渦の構造を考虑に入れて選択吸い込み を行うと，その吸い込みの影響を受けて縌渦はスパン 方向に位置を変えてしまい, 意図した流れ場の吸い込 みができず，結局有効に制御することができないので はないか，との危惧がなされていた。しかしれまでの 実験から，実験条件が同じであれば渦は極めて安定し て常に一定の場所に発生するという事実が判明してい る。これまでの研究結果(10)(11)より，流れ場を乱流遷移 へと導くのは高周波二次不安定性 $f_{2}$ であることがほぼ 明らかになっている. 横流れ渦の運動によって隹面近信 の低速流塊が持ち上げられ，高速流にさらされること により境界層の中層，渦の巻き上がり部分に高せん断 層がスパン方向に周期的に形成される.この高せん断 層内の変曲点形不安定性により $f_{2}$ が形成されると流れ 場注急速に非定常性を有しはじぬ， $f_{2}$ が 8 10凬剘発生 した後に完全乱流へと遷移してしまう。このような讲 実から，持ち上げられる低速流塊を阻むことにより $f_{2}$ の発生を遅らせることが出来るものと考えられる.こ れらのことを考虑して，この渦の巻き上がり部分の根 元に選択的に吸い込み孔列を設け，この部分に集めら れる低速流塊のみを選択して吸い込むことを試みた。

実験は主流速度 $12.3 \mathrm{~m} / \mathrm{s}$ で行なった。 この条件での主 然に高周波二次不安定性 $f_{2}$ が発生する位置は $x / C=0.73$ 付近であり，乱流遷移位置は $x / C=0.77$ 付近である. 吸 い込みを行なう位置は $x / C=0.65 \sim 0.75$ である. $f_{2}$ の発生 点は吸い込み位置中央よりやや後方である。つまり㫦 周波二次不安定性 $f_{2}$ の発生前から, $f_{2}$ が発生し乱流遥移 にいたる直前までの遷移領域で吸い込みを行なってい ることになる.また吸い込み量は $0.03 \mathrm{~m}^{3} / \mathrm{m}^{2} \cdot \mathrm{s}$, 一本の洞 当たりでは $3.3 \times 10^{-3} \mathrm{~m}^{3} / \mathrm{s}$ である。また吸い込み速度は 一様吸い込みの場合が $0.025 U_{\infty}$, 選択吸い込みの場合が 


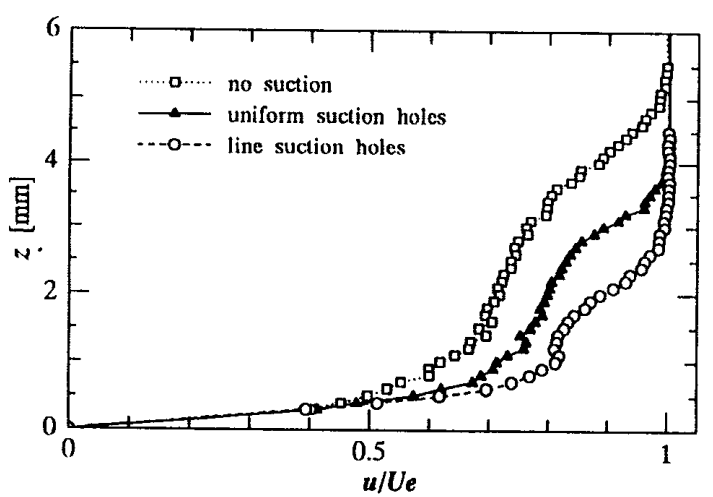

Figure 5. Time-averaged wall normal velocity profiles. $\left(U_{\infty}=12.3 \mathrm{~m} / \mathrm{s}, x / C=0.79, y=-26 \mathrm{~mm}\right)$

$0.07 U_{\infty}$ である.

図3は $x / C=0.79$ に求いて得られた等速度線図と高周 波二次不安定性 $f_{2}$ の分布であり，一様吸い込多と選択 吸い込みによる制御の效果を比較したものである. 図 はド流侧から上流を見たものであり，境界層内の横流 れ速废成分は図の柏向きに分布している.

(a)図は吸い込み涠しの場合であり，横流れ滑はかな り大きく成展し， $f_{2}$ 広い範四に広がっている。 また等 速度線の閒隔も広がり, 境界層厚さも厚くなっているこ とから，乱流遷移直前の状態であることが分かる。 れに対し制御を行った(b), (c)図では, 高周波一次不安定 性 $\int_{2}$ の発生が大幅に抑えられている. しかし(c)図の選 択吸い込双で恃活発生が抑えられているが, (b)図の …様吸い込みではまだ $\int_{2}$ が一部に大きく広がっている。 これより，一様吸い込多よりも選択吸い込多の方が同 じ吸い込み量でより效果的に高周波二次不安定性 $f_{2}$ の 発生を却えることができることが分かる。この理由は, 先にも述べた通り縦渦の巻上がり部分に存在する低速 流塊を選択的に吸い込んでおり，制御のために投入し たエネルギーを有効に高せん断層の発達阻書に使用し ているために，より效果的に制御できたものと考えら れる.

またこの吸い込み孔自体は，吸い込まない状態では 表面粗さとなり，流れ場を乱していると思われる。本研 究では孔の直径が $0.1 \mathrm{~mm}$ と一般に用いられる吸い込み 孔より大きいが，その理由は，遷移領域の厚い境界層位 置で制御寸ることを考えているためである。一様吸い 込みの場合は選択吸い込みの場合に比べ吸い込み孔の 数が多い:このことも選択吸い込みの方が $f_{2}$ の乱れが 少ない一因となっている可能性がある。また二梯吸い 込みでは獚流れ渦の形があまり崩れないで保持されて いるのに刘して，選択吸い込みでは，吸い込みによって 横流れ温の形が変形しており，同じ吸い込み量でもよ り横流れ渦の棈造に影響を与えていることが分かる。

図4は $x / C=0.79, y=-26 \mathrm{~mm}, z=1.2 \mathrm{~mm}$ において熱線流

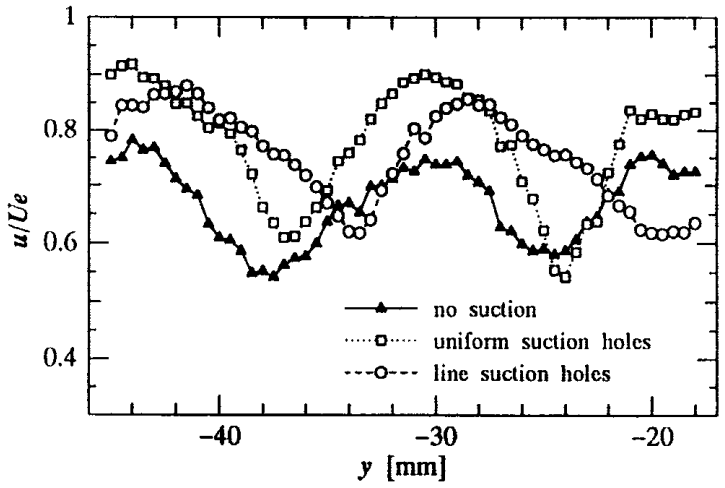

Figure 6. Time-averaged spanwise velocity profiles $\left(U_{\infty}=12.3 \mathrm{~m} / \mathrm{s}, x / C=0.79, z=0.8 \mathrm{~mm}\right)$

速計によって測定された時間速度波形の凮波数船析維 果である。吸い込み無しの場合はほ活活流に近い㫦波 数分布を示している.これに対して一様吸い込为，邀抓 吸い込みの場合では高周波成分がより有效に娍少でき

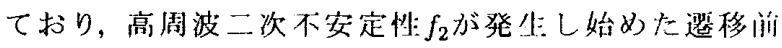
の状態になっていることが分かる。

図 5 は $x / C=0.79, y=-26 \mathrm{~mm}$ において測定された $z$ 万间 の境界層速度分有を示したものである. 境界屏の速度 分有の変曲点形速度公配は，この $y=-26 \mathrm{~mm}$ で㵊も液く なっている。四3の等速度線図からも判断できるが，吸 い込みにより低速流塊の巻上がりが抑えられ，かつ留 曲点高さが低くなっている。 そして，選択吸い込为のj が集中して吸い込んでいる分，上り変曲点の融さが低 くなっている.また変曲点での $z$ 万问の速度勾配 $d u / d z$ も 選択吸い込みの方が小さくなっておう，高せ儿断層の䚲 成が抑制されている. 高周波二次不安定性 $\int_{2}$ は, この変 曲点での $d u / d z か ゙$ 強いほど, 変曲点高さが高いほど䧲生 し易いと考えられるので(15)，これよりも選抓吸い込文 の方が優れていることが分かる.

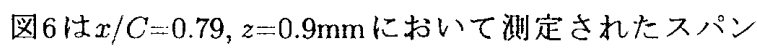
方向の境界層の速度分布を示したものである，選択级 い込みの場合はスパン方向の速度勾配 $d u / d y$ も緩やか になっておりこの測定結果からも変业点形不穴定性で ある高周波二次不安定性 $f_{2}$ が発生しにくくなっている ことが分かる. また選択吸い込みの場合，は收い込办 により高速域，低速域の位置がスパン方向にいく分シ フトしている，選択吸い込みの場合は，吸い込名量を 增やし過ぎると過度に流れ場を変形させてしまい，新 たに変曲点が形成され，逆に $\int_{2}$ の発生が促進されてし まうことが分かっている(11)(16). 陚行鍇誤の結果, 四60) 選択吸い込みの場合の吸い込办量 $0.045 \mathrm{~m}^{3} / \mathrm{m}^{2} \cdot \mathrm{s}$ はその 限界值に近いものだと考えられる。

図7は, 各吸い込み法の違いによる遷移点の変化を收 い込み量をパラメータとして示したものである。ただ し $x / C=0.925$ 以降は压力印加物体の下流僛になってし 


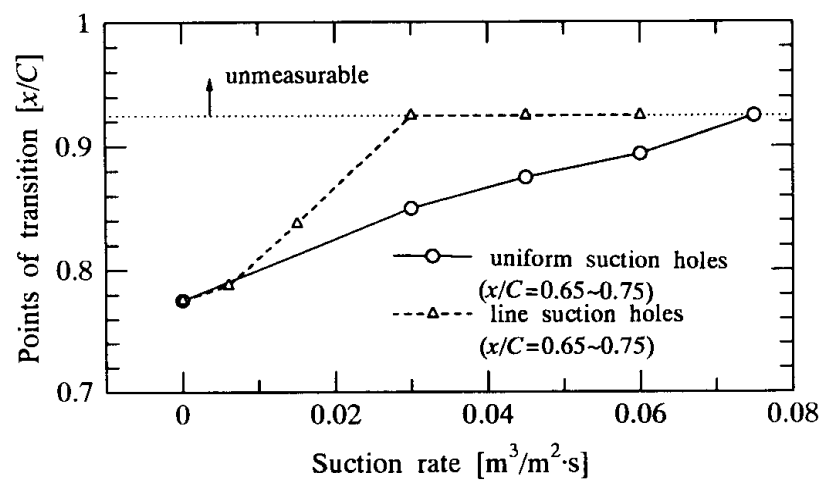

Figure 7. Transition characteristics for distributed suctions $\left(U_{\infty}=12.3 \mathrm{~m} / \mathrm{s}\right)$

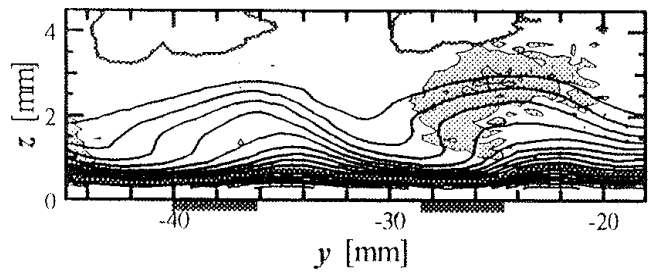

(a) line suction holes at position $A$

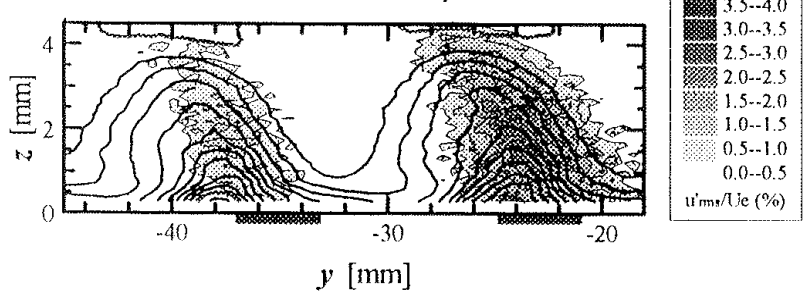

(b) line suction holes at position $B$

Figure 8. Cross sectional measurement of velocity and turbulence intensity profiles for distributed suctions.

(velocity contour line step: $5 \%$ of $U e$,

Bandpass filter range : $1.25-2 \mathrm{kHz}$ for disturbance $f_{2}$, $x / C=0.79, U_{\infty}=12.3 \mathrm{~m} / \mathrm{s}$, Suction volume $0.03 \mathrm{~m} / \mathrm{m}^{3} \cdot \mathrm{s}^{2}$ m indicates suction positions)

まうため測定不能となっている。また遷移点は速度波 形，lFT䦓波数解析結果を参考にしつつ形状係数より 決定した。これより, 選択吸い込みの方が一様吸い込み に比べてより少ない吸い込み量で遷移点を下流に移動 させていることが分かる．例えば $x / C=0.925$ に遷移点 が到達寸る吸い込夕量でタると，選択吸い込みは一様 吸い込みの $1 / 3$ 以下の吸い込み量で同様の制御効果を 得ている.

$3 \cdot 2$ 吸い込み位置を変えた場合(スパン方向) 選 択吸い込みを行う場合は，適切な吸い込み位置を選ぶ ことが重要である. 図8はスパン方向に吸い込み位置 を多少変化させた場合の制御の結果を比較したもので ある.諸条件は図3の場合と同じである. (a) 図のposition A は, 縦渦の巻上がり部分のやや左側(図3と同位 置), (b) 図の position B は巻上がりのやや右側である. 図 より，巻上がりのやや左侧に設置したposition Aがより 効果的であることが分かる。高周波二次不安定性 $f_{2}$ は 壁面近傍の低速流塊が横流れ渦によって持ち上げられ， 高速流にさらされることにより境界層の中層, 縦渦の

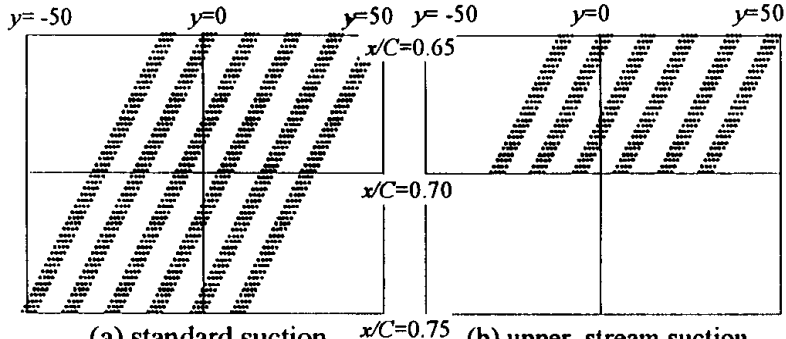

(a) standard suction $x / C=0.75$ (b) upper stream suction

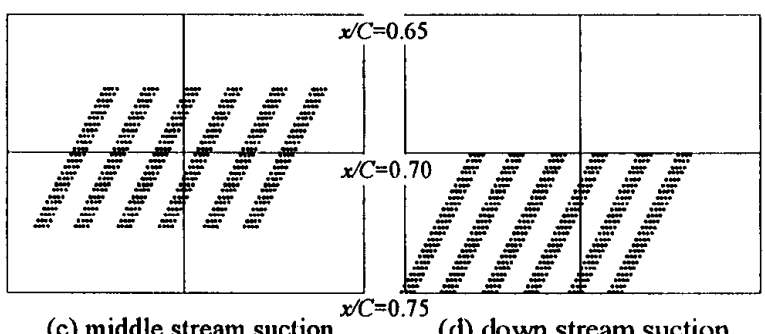

(d) down stream suction

Figure 9. Arrangements of line suction holes

巻き上がり部分に，"高せん断層プラス変曲点”形の分 布がスパン方向に周期的に形成されることによって生 じることは既に述べた. position A は低速流塊の剎流れ 成分が横流れ渦によって持ち上げられる巻上がり自体 を吸い込むと共に，低速流塊を持ち上げられる前に予 め吸い込んでしまっている。これによってposition B は， 渦の巻上がりを吸い込んでいるだけで低速流塊を有効 に吸い込んでいない. よって高せん断層の形成を防ぐ ためには，横流れ速度により縦渦下部に移動して来る 低速流塊を, 渦運動によって巻き上げられる前に吸い込 むことが重要である。

$3 \cdot 3$ 吸い込み位置を変えた場合(コード方向) 吸 い込みによる制御では，遷移領城のどの段階で吸い込 むか，ということも重要な要素となる．図9はここで朋 いた選択吸い込みの配置を示したものである.ここで は, 自然な状態で高周波二次不安定性 $f_{2}$ が $x / C=0.70$ 付 近で発生するように主流速度を $13.5 \mathrm{~m} / \mathrm{s}$ に調整した。 こ の場合の遷移位置は $x / C=0.73$ 付近である.よって図 3 , 図8(a) で用いた選択吸い込みを(a)standardと寸ると,こ のちょうど真ん中で $f_{2}$ が発生することになる: (b)，(c)， (d) はそれぞれ $f_{2} \sigma$ 発生前 $(x / C=0.65 \sim 0.70)$, 発生点 $(x / C=0.675 \sim 0.725)$, 発生後 $(x / C=0.70 \sim 0.75)$ の各 段階で吸い込むことになる。図10はその結果を示して いる. $x / C=0.76$ における等速度線図と高周波二次不安 定性 $f_{2}$ の分布を示したものである.この時の收い込み 量は $0.06 \mathrm{~m}^{3} / \mathrm{m}^{2} \cdot \mathrm{s}$ である.これらの図より, (b) 発生前, (c) 発生点, (d) 発生後の順に $f_{2}$ の発生が抑えられ, 良い效柴 を示すことが分かる. 以上の結果より，吸い込みによる 制御を行う場合は $f_{2} か ゙$ 発生し，非楾形成長が始まる酉 前の線形成長段階で行うのがより效果的であることが 分かる.一旦非線形成長が始まると, 容易には層流制御 


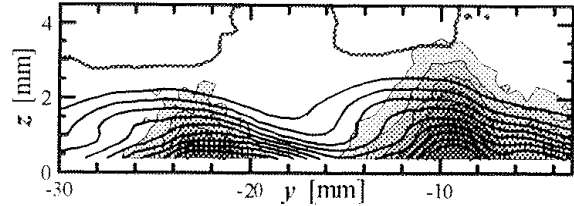

(a) line suction holes (standard)

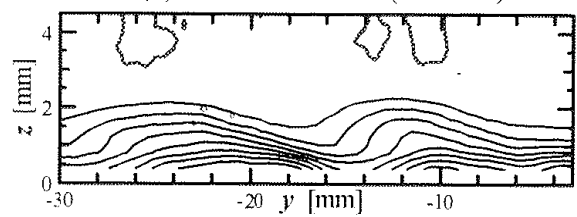

(b) line suction holes (upper stream)

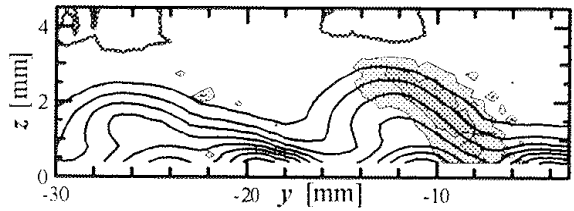

(c) line suction holes (middle stream)

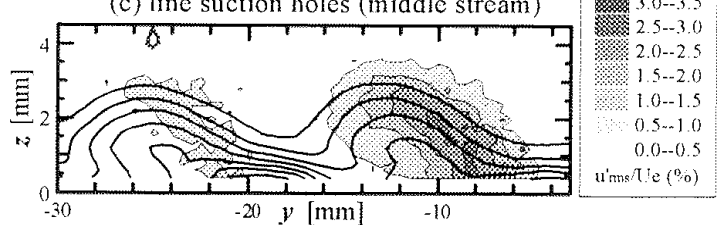

(d) line suction holes (down stream)

Figure 10. Cross sectional measurement of velocity and turbulence intensity profiles for distributed suctions. (velocity contour line step: $5 \%$ of $U e$,

Bandpass filter range : $1.25-2 \mathrm{kHz}$ for disturbance $f$, $x / C=0.76, U_{\infty}=13.5 \mathrm{~m} / \mathrm{s}$, Suction volume $\left.0.06 \mathrm{~m}^{3} / \mathrm{m}^{2} \cdot \mathrm{s}\right)$

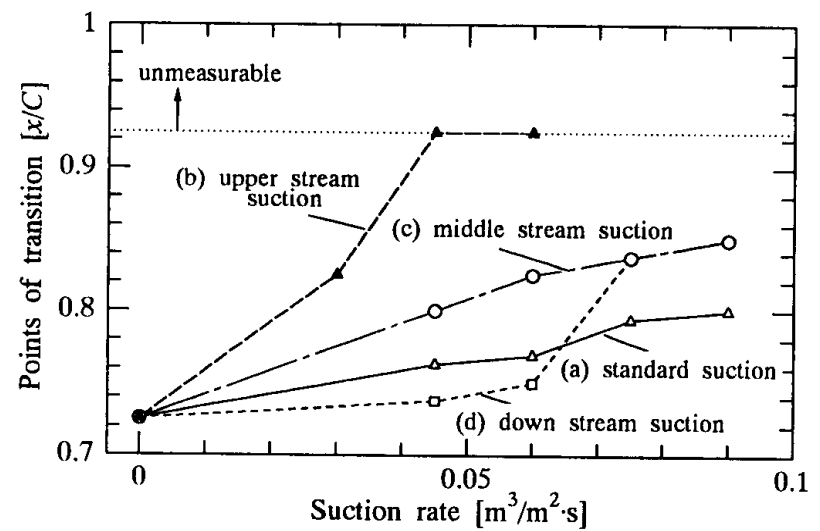

Figure 11. Transition characteristics for line suction holes $\left(U_{\infty}=13.5 \mathrm{~m} / \mathrm{s}\right)$

ぶできないものと思われる.

図11はコード方向の吸い込多位置の違いによる乱流 遷移点の変化を示したものである.この図からも, $f_{2}$ 発 生前に吸い込んだ(b)図の方が他の位置に比べて明ら かに優れていることが分かる. 他のものに比べて $1 / 2 か$ ら $1 / 3$ 以下の吸い込み量で同様の効果を得ることがで きる.また (a)図と (c)図は, ともに吸い込み位置の真ん 中で $f_{2}$ が発生しているにも関わらず，(c)図の方が優れ ている. (a) と (c)の違いは, 吸い込み孔列の長さの違い によって生じる吸い込み速度である。

このように同じ吸い込み位置，同じ吸い込み量であ
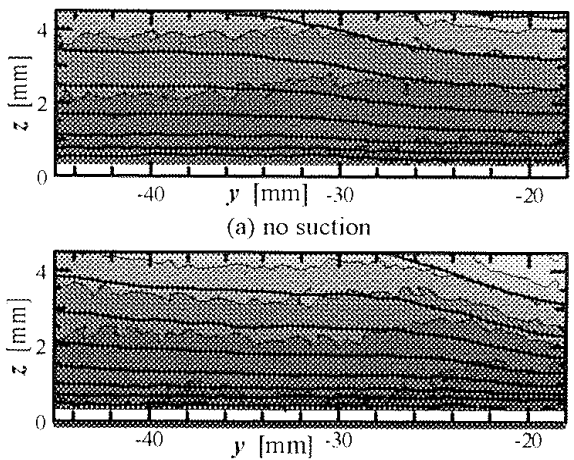

(b) Suction volume $0.03 \mathrm{~m}^{2} / \mathrm{m}^{2} \cdot \mathrm{s}$

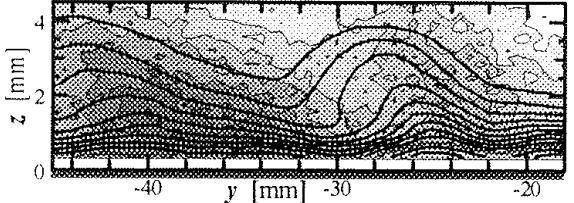

(c) Suction volume $0.045 \mathrm{~m}^{3} / \mathrm{m}^{2} \cdot \mathrm{s}$

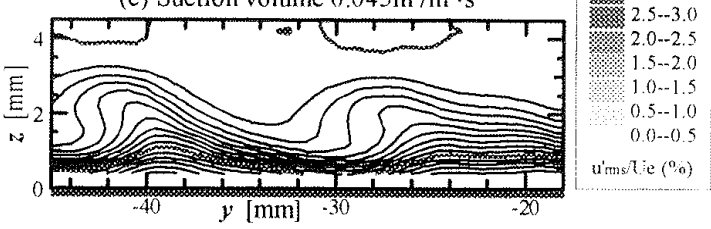

(d) Suction volume $0.06 \mathrm{~m} / \mathrm{m} / \mathrm{s}$

Figure 12. Cross sectional measurement of velocity and turbulence intensity profiles for distributed suction using uniform suction holes. (velocity contour line step: $5 \%$ of $U e$,

Bandpass filter range : $1.25-2 \mathrm{kHz}$ for disturbance $f_{2}$, $x / C=0.79, U_{\infty}=12.3 \mathrm{~m} / \mathrm{s}, \mathbf{m} m$ mm indicates suction positions)

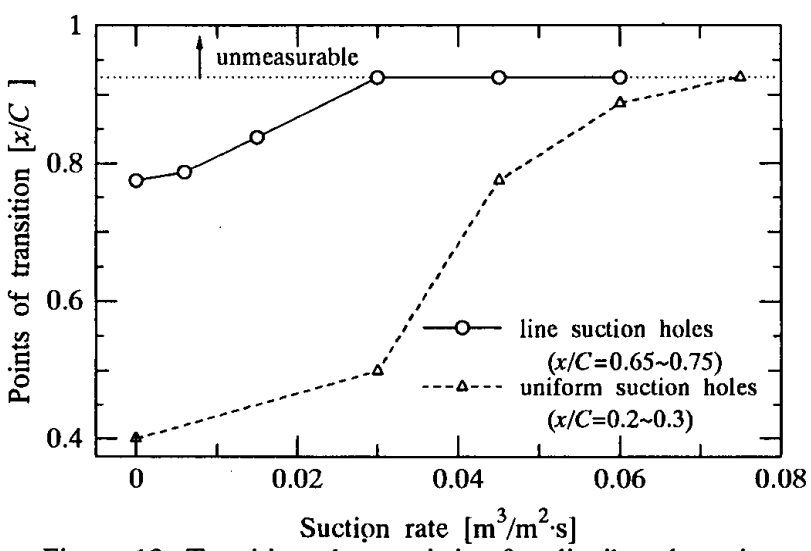

Figure 13. Transition characteristics for distributed suctions $\left(U_{\infty}=12.3 \mathrm{~m} / \mathrm{s}\right)$

っても, 吸い込み速度が速くなると((c)図は(a)図の2 倍) 上り効果的な制御が行えたのは，吸い込多速度が增小 ことでより境界層の高いところまで影響を及ぼすこと ができたためであると考它られる.

$3 \cdot 4$ 前縁付近の吸い込みこれまでは高周波二 次不安定性 $f_{2}$ が発生するかなり下流での吸い込み例御 について詳細にみてきた。しかし過去の吸い込みによ る制御は前縁付近に適用されるものが多かった。 そこ で比較のために, 前縁付近 $x / C=0.2 \sim 0.3$ で一梯吸い込み を行う制御を試みた。この段階ではまだ蓝流れ渦は ほとんど成長していない。図12はこの結果を示した 
$x / C=0.79$ における等速度楾图と高周波一次不安定悱 $f_{2}$ の分有を六したものである。(a)図の吸い込み無しで

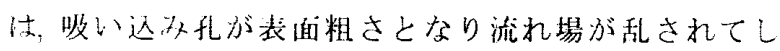
まったため、寸でに分全乱流となっている，隊䋑付近で けまだ境界層は溚くおよそ2.7mmですり，後力での吸 い込みに比べより壁自问の粗さり影響を大きく受け易く なっているためと考えられる。このため, 吸い込双孔を 設置しなふ力場合よりも遷移が早くなっている.

図13 法解付近での一様吸い込みによる遷移点の変

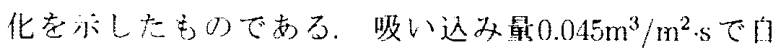
然遷移と间じ所をで戻っている。しかし吸い込み显

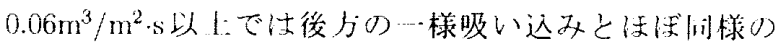
制御の效果をあげていることが分かる.

前項に拈いて吸い这みに上る制御は線形段階で行う のが庭いという結果が得られたが, 境界辟が薄く粘性 形不安定性(T-S 波) が生じ易い前縁付近で制御を行う 際には，吸い远好孔大きさを十分小さくすると间時 に表南粗さによる䍐影響を打ち消寸以トの吸い込みが 必要であると思われる。横流れ淌がほとんど成舆して いない段嘴での㫼御は選抧吸い込みを適用できず,

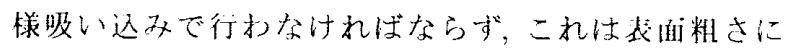
よる患影響の点から不利である。よって二.次元境界層

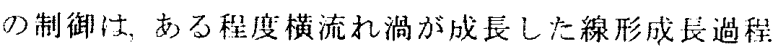
で選択吸い迢多を行うのが良いと考えられる。

\section{4. 結言}

以上，横流れ不安定性が支配的な二次元境界屏の遷 移機構からの情城をもとに，選択吸い込外に上る横流 れ不安定場の制御を行った。 以下に得られた知見を就 小.

(1) 低速流塊が横流れ渦によって巻き上げられる部分 を選択的に吸い込むことにより，効果的に二次元境界 層遷移を制衔することができた。高せん断層の形成を 阻害し高周波一次不安定性 $\int_{2}$ の発生を遅らせることが でき,遷移点はド流へと移動した。この選択吸い込みに よる制御によって‥様吸い込みの場合と比較して1/3以 下のエネルギーで同等の効果を得ることができた。

(2) 選扒吸い远みを行うときは, 横流れ渦の巻きたげ 部分を吸い込むと共に, 巻きトげられる前に横流れ成 分(低速流塊)を吸い込んでしまうことが重要である。

(3)吸い込みによる制御を行うときは，横流れ渦が線 形成長をしている段階で行うことが効果的であること が判明した, 高周波二次不安定性 $f_{2}$ が発生した後, 非線 形成長段階で制御を行うと効果が激減する。
(4) 横流れ渦が成长してい孙い前縁付近において,

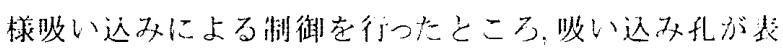
面粗さとなり，们效な效果を得るために沈なり吸い

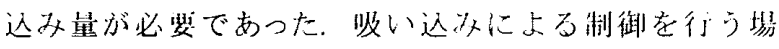

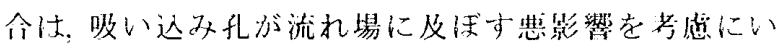

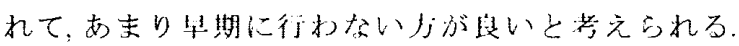

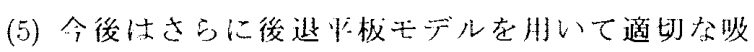
い込子条件を䧓心゙ていく，末た东譏に適用する際には，

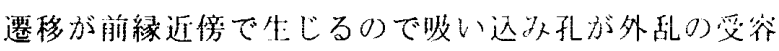

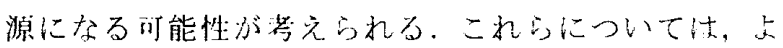
り高いレイノルズ数のデータ方取れる風润を使月し，

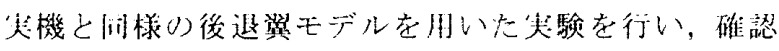
していく必要があると考えられる。

\section{文献}

(1) Gray, W. F, RAL TM Aem 255, (1952).

(2) Gregory, N., Stuart, J. T., Walker, W. S., Phil. Thuns. Roy. Soc. Lond., A 248 (1955), 155 - 199.

(3) Kohama, Y., Turbulent Management and Relaminarization. Springer-Verlag, (1987), 19-23.

(4) Radezlsky Jr., R. H., Reibert, M. S., Saric, W. S., Takagi, S., AIAA Pap., No. 93-0070.

(5) Takagi, S., Itoh, N., Fluid Dynamics Rescurch, 14, (1994). $167-189$

(6) Dalmamn, U., Bieler, H., ALAA Pap., No. 87-1337.

(7) Meyer, F., Kleiser, L., Dallmann, U., Proc. AGARD Sympo. on Flaid Dynamics of Three-Dimensional Tirrbulent Shear Flows and Trarisition, Turkey, (1988), 17-1-17-17.

(8) Balakumar, P., Malik, M. R., Theoret. Comput. Fluid Dynamics, 3 (1991), 125-140.

(9) Saric, W. S, and Yeates, L. G., Laminar-Turbulent Transition, Springer-Verlag, (1985), $429-437$.

(10) Kohama, Y., Onodera, T., Egami, Y., Nonlinear Instability and Transition in Three-Dimensional Boundary Layers, Kluwer Academic Publishers, (1996), 147-156.

（11）汭:上泰㕕，小演泰昭，小野辌達也，機論，63-607，B (1997)， $849-856$

(12) Saric, W. S., Hoos, J., Kohama, Y., College of Engineering and Applied Science Report, Arizona State Univ., (1990), CEAS-CR-R-90191.

(13) Poll, D. I. A., Laminar-Turbulent Transition, Springer-Verlag. (1989), 431-440.

(14) Ito, H., Kobayashi, R., Kohama, Y., Aeron. J., (1992), 141151.

(15) Kohama, Y., Fukunishi, Y., Wang, T., JSME. International J., 36 (1993), 74-79.

(16) Myose, R. Y., Blackwelder, R. F., AIAA J., 33 (1993), 10761080 .

\section{謝辞}

本研究を遂行するに際し，多大なる御協力を頂いた 流体科学研究所技官太出福雄氏，及び同付属工場技官 渡辺努氏, 浅野和夫氏に感謝の意を表し末す。 